\title{
Dynamic Classroom Strategies to Address Learning Diversity
}

\author{
Shreeranga Bhat ${ }^{1 *}$, Rio D'Souza ${ }^{2}$, E.S.M. Suresh ${ }^{3}$, Sathyendra Bhat ${ }^{4}$, Ragesh Raju ${ }^{5}$, Vinayambika S. Bhat ${ }^{6}$ \\ ${ }^{1}$ Department of Mechanical Engineering, St Joseph Engineering College, Mangaluru, Karnataka, India \\ ${ }^{2}$ Department of Computer Science and Engineering, St Joseph Engineering College, Mangaluru, Karnataka, India \\ ${ }^{3}$ Department of Civil and Environmental Engineering, National Institute of Technical Teachers Training and Research, \\ Chennai, Tamilnadu, India \\ ${ }^{4}$ Department of Computer Applications, St Joseph Engineering College, Mangaluru, Karnataka, India \\ ${ }^{5}$ Department of Computer Applications, St Joseph Engineering College, Mangaluru, Karnataka, India \\ ${ }^{5}$ Department of Electronics and Communication Engineering, Mangalore Institute of Technology and Engineering, \\ Moodabidri, Karnataka, India \\ ${ }^{1 *}$ shreerangab@sjec.ac.in \\ ${ }^{2}$ riod@sjec.ac.in \\ 3 esmsuresh@gmail.com \\ ${ }^{4}$ sathyendrab@sjec.ac.in \\ ${ }^{5}$ rageshr@sjec.ac.in \\ 6vinayambika09@gmail.com
}

\begin{abstract}
Diversity is inevitable in every walk-of-life, and rightly in the learning process. Lack of strategies to address the need for diversified learning style is one of the stumbling-blocks for achieving the desired outcome among the students. The purpose of the research is to dwell deeper into the pedagogies of engagement to establish the strategies to accommodate diversity in learning style withing each session. The objective is to create a framework for resolving the issues of learning diversity through dynamic classroom strategies. Action Research Methodology is adopted to deploy and unearth the feasibility of strategies to resolve issues of learning styles. Silverman-Felder's learning style approach is used to create a dynamic classroom. Also, statistical techniques are used to draw the inference and to determine the effectiveness of the established strategies to resolve the learning issues. The study indicated that learning styles could be effectively addressed in every session through meticulous planning and deployment of active learning methodology. The dynamic classroom approach has resulted in the achievement of the desired outcome, which was validated through the assessment at the end of the session. Besides, the strategies adopted are validated by comparing the outcome of the other section through the internal test. Also, feedback of the students substantiated the methodology adopted to resolve the issues of diversity in learning styles. The study culminates that learning diversity can be addressed effectively only when the tutor is aware of learning styles and active learning strategies. Also, it is ascertained that the meticulous planning assists the faculty in ensuring valueadded activities in the session. In addition, well-established
\end{abstract}

\section{Shreeranga Bhat}

Department of Mechanical Engineering, St Joseph

Engineering College, Mangaluru, Karnataka, India

shreerangab@sjec.ac.in

rubrics helps the students to understand the framework within which they need to participate in the session. Besides, motivation connected to the emotions helps the students participate proactively. Eventually, it is determined that the scientific planning of the session brings socio-technical changes among the students and in the system.

Keywords: Learning Diversity, Dynamic Classroom, Outcome Based Education, Active Learning

\section{Introduction}

Formulating a comprehensive plan of action is of paramount importance about students' learning styles in deploying student-centric pedagogy of engagement (Tickle, 2001; Yousef, 2016). The mismatch between the learning styles of students and pedagogy of engagement may lead to demotivation in continuous learning (Gilakjani, 2012). The Outcome Based Education (OBE) demands comprehensive understanding and deployment of effective active learning strategies to address the learning styles of all the students (Binu et al., 2020). Also, effective management of individual learning differences and associated tools, more specific application of Felder-Silverman Learning Style models is need of the hour to attain desired outcome OBE framework (Graf et al., 2007). In addition, it is vital to adopt better active learning methodologies which completely change the environment in the classroom to transform lethargic personalities into a brimming student (Bhat et al., 2020a). Moreover, 'Lowman's 2-D Model of Teaching' need to be dwelled deeper not only to comprehend teacher's teaching styles but also to ascertain out teaching style to cater the needs of diversified learning styles among the students. Eventually, it will assist the tutor to differentiate the 'Good Teacher' and the 'Bad Teacher' from students' perspective and ensures better pedagogies of engagement from spectrum students learning styles (Lowman, 1995).

The tutor should not impose their learning styles on to the students, rather must comprehend the students learning styles for effective deployment of OBE. Assessment of students learning styles is the very essence of the OBE. It must be the first step in the design of dynamic classroom 
prior to the planning of the teaching-learning process (Bhat et al., 2020c). Moreover, when learning diversities are not addressed, it leads to a mind-numbing session, low attendance, and students' poor performance in tests (Felder and Silverman, 1988; Felder, 1993).

Thus, the purpose of the research is to dwell deeper into the pedagogies of engagement to establish the strategies to accommodate diversity in learning style withing each session. More specifically, the objective is to create a framework for resolving the issues of learning diversity through dynamic classroom strategies in the OBE system. Above factors motivated the researchers to frame the following Research Questions (RQs):

RQ1: What are the strategies to address the learning diversities among the students?

RQ2: How to create a dynamic classroom to cater to the needs of learning styles?

RQ3: What are the various steps involved in establishing dynamic classroom strategies to attain the desired outcome?

\section{Literature Review}

It has been determined that information/ knowledge processing among the students takes place in different ways such as acting and reflecting, visualizing and hearing, rationalizing and intuiting, visualizing and analyzing. Then they will be able to recollect and apply based on the level of learning (Felder and Henriques, 1995). This diversification is not only found in students but also among the tutors who disseminate the knowledge (Felder and Spurlin, 2005). The teachers adapt different teaching styles depending on their strengths such as lecturing, demonstration, project-based teaching, problem-based teaching, blended methodology, memorizing, and other pedagogies of engagement (Bhat et al., 2020b). When the teacher's teaching style does not match with the students' learning style, the session may lead to mind-numbing exercise, and divert the attention of students from learning. The cascading effect of same can be observed in the form of low attendance, poor test results, demotivation from the course, curriculum, and eventually college dropouts (Litzinger et al., 2007).

The teacher may adopt different course correction strategies, including critical to the student's behaviour, demotivating himself from the profession and inadequate preparation to the session. This may lead to a change of profession or job loss and system may lose a potential professor. These challenges confronted by the teacher can be overcome by comprehending the learning diversity among the students and framing effective strategies based on the spectrum of pedagogies of engagement (Felder and Brent, 2005). The OBE demands a more balanced approach than teaching each student according to their learning style separately. These balance approach ensures effective dissemination of knowledge/ information with the optimal utilization of available resources and assists the students to embrace different learning styles. These, in turn, prepares the students to learn efficiently and effectively irrespective of teaching style in the long run (Felder, 1996).

One of the learning style models established by the educational psychologist, Felder and Linda K. Silverman popularly known as 'Felder-Silverman Model' may assist the teachers to address the issue of learning diversity among the students. The learning styles and strategies as per the 'Felder-Silverman Model' is shown in Table 1. Effective adoption of these strategies may lead to efficient content delivery and better attainment/ results by the students (Felder and Silverman, 1988; Felder, 1993). Thus, the present research work intended to tap the potential of this model to ensure dynamic classroom and to make sure better curriculum delivery.

Table 1: Felder-Silverman Model - Learning Styles

\begin{tabular}{|c|c|c|c|}
\hline Category & Learning Styles & Meaning & Strategies \\
\hline \multirow[t]{2}{*}{ Input } & Visual & Prefer visual presentation material & $\begin{array}{l}\text { Adopt strategies such as explanation through flow } \\
\text { charts, figures, images, timelines, video, concept maps, } \\
\text { demonstrations, digital resources, notes with different } \\
\text { colours. }\end{array}$ \\
\hline & Verbal & $\begin{array}{l}\text { Prefer explanation with words (both } \\
\text { written and spoken) }\end{array}$ & $\begin{array}{l}\text { Summarize the topic, group works, peer listening and } \\
\text { teaching }\end{array}$ \\
\hline \multirow[t]{2}{*}{ Processing } & Active & $\begin{array}{l}\text { - Comprehend by doing something } \\
\text { with the information. } \\
\text { - Prefer to process the information } \\
\text { by talking about it and trying it out }\end{array}$ & $\begin{array}{l}\text { Adopt pedagogies such as Group studies and peer } \\
\text { teaching/listening, mock quiz, test. }\end{array}$ \\
\hline & Reflective & $\begin{array}{l}\text { - Comprehend by thinking about } \\
\text { information. } \\
\text { - } \begin{array}{l}\text { Prefer to think things through and } \\
\text { understand things before acting }\end{array}\end{array}$ & $\begin{array}{l}\text { Discuss applications of the concepts, pause and recall, } \\
\text { promote short summaries of reading in own words }\end{array}$ \\
\hline \multirow[t]{2}{*}{ Perception } & Sensing & 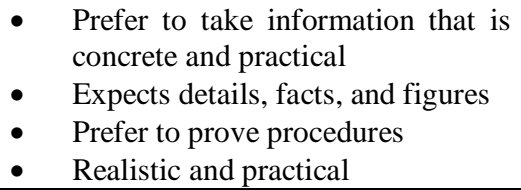 & $\begin{array}{l}\text { Provide facts and procedures, relevant and specific } \\
\text { examples, practical applications, evaluate the } \\
\text { alternatives. }\end{array}$ \\
\hline & Intuitive & Prefer to take in information that is & Find and connect the facts, do not repeat too many \\
\hline
\end{tabular}




\begin{tabular}{|c|c|c|c|}
\hline & & $\begin{array}{l}\text { abstract, original and theory- } \\
\text { oriented } \\
\text { - } \begin{array}{l}\text { Expect the big picture and the } \\
\text { overall pattern }\end{array} \\
\text { - Discover relationships and ideas }\end{array}$ & times, avoid memorizing approach. \\
\hline \multirow[t]{2}{*}{ Understanding } & Sequential & $\begin{array}{l}\text { - } \quad \text { Prefer to organize the information } \\
\text { in a linearly and orderly way } \\
\text { - Expects logically sequenced steps } \\
\text { and organized information }\end{array}$ & $\begin{array}{l}\text { Ensure steady progressing of information and avoid } \\
\text { jumping of theories/ steps }\end{array}$ \\
\hline & Global & 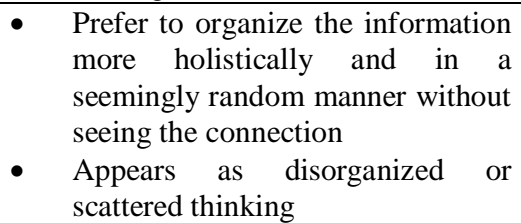 & $\begin{array}{l}\text { Preview the chapter, show the big picture, explain } \\
\text { context and relevance, provide the picture of an } \\
\text { advanced topic, spend a large amount of time on the } \\
\text { topic, promote ideation. }\end{array}$ \\
\hline
\end{tabular}

\section{Research Methodology}

The current study is based on the Action Research (AR) methodology. AR is a variation of the case study methodology. In AR methodology, the researcher not only an independent observer but also participant in the process (Prybutok and Ramasesh, 2005; Schein, 2008). This is the most preferred methodology for engineering education research as it ensures organizational change by simultaneously studying the process involved (Avison et al., 2001; Reason and Bradbury, 2008). Moreover, it promotes the active involvement of the members from the organization under study. Also, it is one of the ideal methodologies for the exploratory nature of the study. The methodology treats research and action as inextricably interwoven aspects.

Further, it brings together theory and practical solutions to develop practical knowledge in the pursuit of knowledge (Reason and Bradbury, 2008). The teacher, being the researcher, has involved in the development of a case study, and the research was performed on the same group of students over two years of their studies in engineering. Moreover, it combines theoretical and practical solutions to evolve practical applications (Bhat et al., 2020a). Further, CDOV (Concept-Design-Optimize-Verify) approach of Lean Six Sigma product/service development phases are used for project deployment and sustainment (Bhat and Jnanesh, 2013).

In addition, Silverman and Felder's Learning model was used to comprehend the learning styles of both teacher and students (Felder and Silverman, 1988; Felder, 1993). The teacher, being the researcher, was directly engaged in developing the case study, and the research was conducted on the group of students belonging to a specific semester for a subject named as "Management and Engineering Economics" to obtain the answers for the research questions. Different active learning strategies have been utilized to address learning diversity. A total of 50 students took part in the study. Two sample T-Test, ANOVA and Boxplots were used to draw the robust inference.

\section{Case Study}

The current project was deployed in the BE program of Mechanical Engineering specialization at $5^{\text {th }}$ semester in a section consisting of 50 students. The project was conducted for the subject 'Management and Engineering Economics', and the sub-topic 'Planning' was taken into account for the deployment of Collaborative learning approach under the umbrella of CDOV phases for the structured deployment strategy. The topic was planned to be completed within 4 Lecture hours with macro and micro level planning for every lecture hour. Further, during the classroom, student engagement, a comprehensive strategy was adopted to ensure a dynamic classroom that addresses the learning diversity across the topic of discussion. The project was executed through the following phases.

\section{A. Concept}

In this phase, a holistic strategy will be developed to ensure customer delight by capturing the process with Input, Action, and output. The phase is intended to determine CTS (Critical to Satisfaction) characteristics. Thus, a brainstorming session was established with pioneers in the field of education to determine the CTS to address the learning diversity, and same is validated through the experts associated with IUCEE (Indo-Universal Collaboration for Engineering Education) consortium. Following strategies have been taken into account to address learning diversity among the students.

1. Motivate: Relate new material to previous and future topics/courses (sequential, global)

2. Provide a balance of concrete information (sensing) and abstract concepts (intuitive)

3. Balance practical problem solving (sensing/active) with fundamental understanding (intuitive/reflective)

4. Provide illustrations of intuitive patterns such as logical inferences and sensing patterns such as observations. Encourage all students to exercise both sensing and intuitive learning

5. Provide concrete examples of phenomena described by theory (sensing); then develop a theory (intuitive, sensing); show how theory can be validated and deduce consequences (sequential), present applications (sensing/sequential)

6. Use pedagogies such as pictures, schematics, graphs, demos before, during and after verbal material is shown (sensing/visual). Use hands-on demos when possible (active)

7. Use computer-assisted instruction (sensing/active)

8. Pause to allow time for reflection (reflective) 
9. Plan active learning activities such as 5-minute brainstorming (active)

10. Assign some drills for practice (sensing/active/sequential). Assign problems requiring analysis and synthesis (intuitive/reflective/global)

11. Encourage cooperative learning on HW (active)

12. Encourage creative solutions (intuitive/global)

13. Talk to students about learning styles during advising in class. Have them take the LS Inventory. Explain how they can help themselves.

Based on the above input, a comprehensive plan was chalked out, as shown in Table 2, which addresses all the learning styles by correlating the 13 strategies established based the inputs from the experts.

\section{B. Design}

This phase intended to bring robustness to the process by system design and functional mapping. Thus, the system design was established by carrying out risk analysis for the sub-topics to be covered in the subject. Table 3 shows the macro-level system design and with mapping to the strategies. Further, during the phase, it was decided to adopt the following points for the successful deployment of the project.

- Sharing the entire plan of the session in advance will help the students to envisage the happenings and to prepare mentally for the class.

- Meticulous planning assists the faculty to ensure only value-added activities in the session.

- Rubrics help the students to understand the framework within which they need to participate in the session.

- Motivation connected to the emotions (Student of the day/ informing their parents) helps the students participate proactively.

- Scientific planning of the session brings sociotechnical changes among the students and in the system.

\section{Optimize}

The objective of this phase is to ensure robust service design by ensuring robust performance and activity/ pedagogy engagement design. Thus, an activity was planned in line with the expected student outcome, as shown in Table 4 and 5. Further, risk analysis (Table 6) was carried to avoid the backlash during the deployment. After the implementation of the Activity-1, lesson learned and scope for improvement was documented (Table 7) to optimize the service design. Following were the factors taken into account to further optimized the service design based on the Activity-1.

- Establishing an e-portfolio for each session consisting of materials, templates, rubrics, along with a brief video address by the faculty to encourage and emphasize the importance of the session.

- Co-teaching during the session may help to break the monotony.

- Ensuring the valuation of the discussion by the other teachers and a few students who will not be part of the discussion during that session.

- Providing on-spot prizes to ensure active learning.

- Establishing a 'Take Away' sheet/file for the session with stickers prepared by the faculty to culminate the discussion at every stage of the session.

\section{Verify}

This objective of this stage is to test and verify the process to meet customer expectations. Based on the lessons learned from the Activity-1, researchers implemented Activity-2, as shown in Table 8. In line with the first activity, the second activity was planned to have the question 'How to apply the Elements of Planning to enhance the action plan that has been already established on achieving 'First Class Distinction in the current semester'? with the following requirements:

- Individual students must create an action plan in advance before coming to the classroom about "how to get First Class Distinction?" prior to the nitty-gritty of 'Planning Elements' which will be discussed during the Activity-1.

- By participating in the Activity-1, students will have a better understanding of the 'Elements of Planning' and expected to enhance the plan according to the requirement.

Further, Longitudinal Study was followed by repeating the strategy followed in the first activity such as linking methodology and outcome (Table 9) and risk analysis (Table 10) even for the second activity during the planning stage. Later, lessons learned, and corrective actions based on the second activity was adopted to enhance the deployment of subsequent activities/ sessions.

Table 2: Project Charter to address learning diversity

\begin{tabular}{|c|c|c|c|}
\hline $\begin{array}{l}\text { Course Topic } \\
\text { or Sub-Topic }\end{array}$ & Strategy & Description & Learning style addressed \\
\hline $\begin{array}{l}\text { Planning - the } \\
\text { importance of } \\
\text { planning }\end{array}$ & $\# 1$ & $\begin{array}{l}\text { Post the Learning style inventory link in Google classroom to take part } \\
\text { in the survey, and to communicate the same with faculty to determine the } \\
\text { spectrum of learners. } \\
\text { Show motivational videos to delineate the importance of planning. } \\
\text { - 'Jio' Case study on planning business strategy } \\
\text { Airtel was planning to counterattack the same. } \\
\text { Provide templates to derive the information and steps in planning }\end{array}$ & $\begin{array}{l}\text { Sequential, Global } \\
\text { Sensing, Intuitive }\end{array}$ \\
\hline
\end{tabular}




\begin{tabular}{|c|c|c|c|}
\hline $\begin{array}{l}\text { Course Topic } \\
\text { or Sub-Topic }\end{array}$ & Strategy & Description & Learning style addressed \\
\hline & $\begin{array}{l}\# 7 \\
\# 8\end{array}$ & $\begin{array}{l}\text { Add few quizzes in between the video to grab and sustain the attention } \\
\text { of students } \\
\text { Break/pause for the reflection after } 2-3 \text { minutes during the video play }\end{array}$ & $\begin{array}{l}\text { Sensing, active } \\
\text { Reflective }\end{array}$ \\
\hline \multirow[t]{2}{*}{$\begin{array}{l}\text { Planning - steps } \\
\text { and premises }\end{array}$} & $\# 2, \# 9$ & $\begin{array}{l}\text { - Students need to derive information from the above case studies } \\
\text { regarding the planning premises and steps involved through } \\
\text { brainstorming. } \\
\text { - Students shall develop the concrete steps in planning }\end{array}$ & Intuitive, active \\
\hline & $\# 3, \# 10, \# 12$ & $\begin{array}{l}\text { - Create a group of } 4 \text { students deriving them from different places } \\
\text { within the class, and assign the role of CEO, Marketing Manager, } \\
\text { Technical Manager, and HR Manager to ensure positive } \\
\text { interdependency, individual and accountability (Cooperative } \\
\text { Learning). } \\
\text { - Discussion and presentation from the students' group on the topic } \\
\text { "If you are the manager, what are the plans and strategies to } \\
\text { rejuvenate Airtel in the market". } \\
\text { - Provide templates of planning and strategy before the discussion }\end{array}$ & Intuitive/Reflective/Global \\
\hline \multirow[t]{2}{*}{$\begin{array}{l}\text { Planning - } \\
\text { framework }\end{array}$} & $\# 6$ & $\begin{array}{l}\text { Ask the students to prepare a poster based on their above discussion as an } \\
\text { action plan for Airtel }\end{array}$ & Sensing, Visual, Active \\
\hline & $\# 13$ & $\begin{array}{l}\text { Discuss the methodology adopted with this planning sheet to address the } \\
\text { learning styles of students. Emphasize on the balanced approach towards } \\
\text { learning styles. }\end{array}$ & \\
\hline
\end{tabular}

Table 3: Risk Analysis (Pre-implementation Reflection)

\begin{tabular}{|c|c|c|c|c|}
\hline \\
\hline $\begin{array}{l}\text { SI. } \\
\text { No. }\end{array}$ & Topic & Strategy & Potential Risk & Corrective action \\
\hline 1 & $\begin{array}{l}\text { Planning - } \\
\text { Importance } \\
\text { of planning }\end{array}$ & 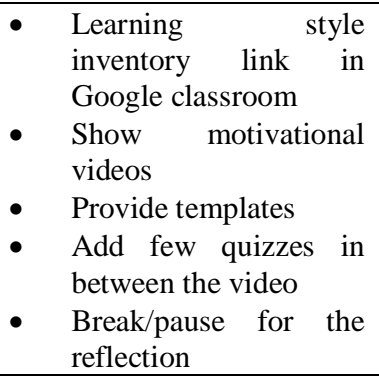 & $\begin{array}{ll}\text { Low response to survey } \\
\text { as not aware of learning } \\
\text { style in advance } \\
\text { Mind-numbing excise } \\
\text { and limited participation } \\
\text { during the video play and } \\
\text { quiz } \\
\text { Minimum involvement } \\
\text { during the reflection }\end{array}$ & $\begin{array}{l}\text { - Share the precise and concise information in } \\
\text { google classroom about learning style and its } \\
\text { essential for students } \\
\text { - Share the videos and entire plan of action } \\
\text { planned for the session in advance in Google } \\
\text { Classroom } \\
\text { Ensure better speakers and the minimum } \\
\text { speed of the fan in the class. } \\
\text { - Creating the group in advance and } \\
\text { disseminating the same through WhatsApp }\end{array}$ \\
\hline 2 & $\begin{array}{l}\text { Planning - } \\
\text { Steps and } \\
\text { premises }\end{array}$ & 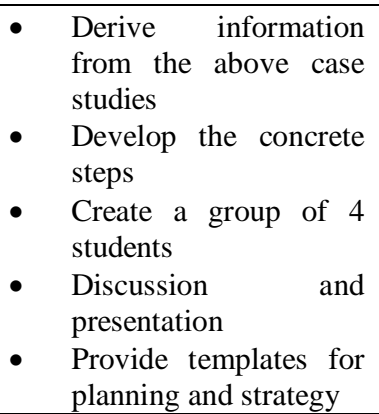 & 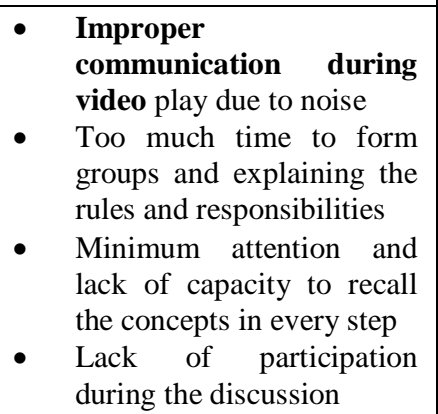 & 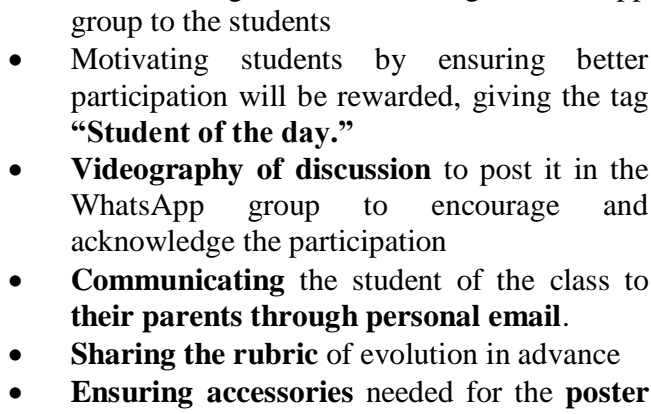 \\
\hline 3 & $\begin{array}{l}\text { Planning - } \\
\text { Framework }\end{array}$ & $\begin{array}{l}\text { - Ask the students to } \\
\text { prepare a poster }\end{array}$ & $\begin{array}{l}\text { - Non-availability of sheets } \\
\text { or other accessories for } \\
\text { chart preparation }\end{array}$ & \\
\hline
\end{tabular}

Table 4: Rationale for the selection of topic and pedagogy of engagement (Activity 1)

\begin{tabular}{|c|c|c|c|c|}
\hline $\begin{array}{c}\text { Topic/ } \\
\text { Subtopic }\end{array}$ & Rational & $\begin{array}{c}\text { Pedagogy of } \\
\text { engagement }\end{array}$ & Rational \\
\hline $\begin{array}{c}\text { Elements } \\
\text { of }\end{array}$ & $\begin{array}{c}\text { The topic needs a } \\
\text { practical } \\
\text { perspective and } \\
\text { Planning } \\
\text { Britical thinking }\end{array}$ & $\begin{array}{c}\text { Clended Learning } \\
\text { Case-based and } \\
\text { Cooperative } \\
\text { learning) }\end{array}$ & $\bullet \begin{array}{l}\text { To ensure students comprehend the concept by undergoing Inductive } \\
\text { Teaching methodology. } \\
\text { The case study helps the students to understand from the practical aspects, } \\
\text { and collaborative learning helps them to deal with team dynamics in the }\end{array}$ \\
\hline
\end{tabular}




\begin{tabular}{|l|c|c|c|}
\hline $\begin{array}{c}\text { to apply } \\
\text { learnings in the } \\
\text { real world. }\end{array}$ & Time: $5 \mathrm{~min}$ & $\begin{array}{l}\text { corporate world [4]. } \\
\text { This team-based learning is essential as planning takes place in a team rather } \\
\text { than at individual levels at Industries [5]. }\end{array}$ \\
\hline
\end{tabular}

Table 5: Methodology and expected outcome (Activity 1)

\begin{tabular}{|c|c|}
\hline Methodology/Plan & $\begin{array}{c}\text { Expected Outcome } \\
\text { At the end of the activity, the students will be able to }\end{array}$ \\
\hline $\begin{array}{l}\text { 1. A Group of } 4 \text { Students will be formed to have effective } \\
\text { engagement and to deal with group dynamics [5]. } \\
\text { 2. A time of } 5 \text { Minutes is allotted for the activity. } \\
\text { 3. Submit the answers, which consist of } 7 \text { elements to be } \\
\text { identified. } \\
\text { 4. The leader within the team should be selected by the team } \\
\text { members to note-down all the points/Answers. } \\
\text { 5. Submit the answers in the templates provided, which consists of } \\
\text { the rubric of evaluation. }\end{array}$ & $\begin{array}{l}\text { - Understand the team dynamics and apply the interpersonal } \\
\text { skill to deal with the same. } \\
\text { Adopt the culture of collaborative learning by critically } \\
\text { thinking about the given situation. } \\
\text { - Analyze the question by synchronizing the theory and } \\
\text { practice related to the subject. }\end{array}$ \\
\hline
\end{tabular}

Table 6: Pre-implementation Reflection (Activity 1)

\begin{tabular}{|l|ll|}
\hline \multicolumn{2}{|c|}{ Potential Risk } & \multicolumn{1}{c|}{ Corrective action } \\
\hline$-\begin{array}{l}\text { Risk of minimum } \\
\text { involvement during } \\
\text { reflection and analysis. } \\
\begin{array}{l}\text { Too much time to form } \\
\text { groups and explaining the } \\
\text { rules and responsibilities }\end{array}\end{array}$ & $\bullet \begin{array}{l}\text { Share the information in Google classroom about the activity to perform. } \\
\text { Creating the group in advance and disseminating the same through WhatsApp group to the } \\
\text { students. } \\
\text { Risk of non-availability } \\
\text { round table to foster the } \\
\text { group discussion in the day." } \\
\text { typical Indian classroom. }\end{array}$ & $-\begin{array}{l}\text { Communicating the best group of the class to their parents through personal email. } \\
\text { Establishing an e-portfolio for each session consisting of materials, templates, rubrics, along with } \\
\text { a brief video address by the faculty to encourage and emphasize the importance of the session. } \\
\text { Providing on-spot prizes to ensure active learning. } \\
\text { Establishing a 'Take Away' sheet/file for the session with stickers prepared by the faculty to } \\
\text { culminate the discussion at every stage of the session. }\end{array}$ \\
\hline
\end{tabular}

Table 7: Post-implementation Reflection (Activity 1) Lessons Learned

1. Sharing the entire plan of the session in advance will help the students to envisage the happenings and to prepare mentally for the class.

2. The prize, on the spot, may boost participation.

3. Rubrics help the students to understand the framework within which they need to participate in the session.

4. Motivation connected to the emotions (Student of the day/ informing their parents) helps the students participate proactively.

5. Inductive teaching with a small group has a significant impact on learning and building the teams.

6. The blended methodology is best suited in the Indian context due to the limited availability of the resources and type of the ecosystem.

\section{Scope for Improvement}

1. A heterogeneous team can be framed by taking into account the learning styles of students to foster the learning.

2. Need to set up the discussion table moving the bench and desks within the classroom to address the significant issues of typical Indian classroom.

3. The activity timeline should be extended to $\mathbf{1 0}$ minutes to help the teams to select their team leaders and to distribute the work among themselves.

4. Blended inductive teaching methodology demands more time for active learning in the classroom.

Table 8: Rationale for the selection of topic and pedagogy of engagement (Activity 2)

\begin{tabular}{|c|c|c|c|}
\hline $\begin{array}{c}\text { Topic/ } \\
\text { Subtopic }\end{array}$ & Rational & $\begin{array}{l}\text { Pedagogy of } \\
\text { engagement }\end{array}$ & Rational \\
\hline $\begin{array}{l}\text { Elements } \\
\text { of } \\
\text { Planning }\end{array}$ & $\begin{array}{l}\text { Students should be able to } \\
\text { analyze and apply the } \\
\text { learnings to simple tasks of } \\
\text { their life before elevating } \\
\text { themselves to address } \\
\text { complex problems of the } \\
\text { corporate world }\end{array}$ & $\begin{array}{c}\text { Writing } \\
\text { Assignment } \\
\text { Time: } 10 \\
\text { min }\end{array}$ & $\begin{array}{l}\text { - The first activity has helped the students of a few learning styles, where } \\
\text { are current activity will address a few more learning styles in order to } \\
\text { reach every student. } \\
\text { Writing the assignment and revisiting the same may help the students to } \\
\text { adopt the culture of critical thinking [6]. } \\
\text { This individual-based activity helps the students embrace creativity and } \\
\text { innovation in planning and presenting the ideas. }\end{array}$ \\
\hline
\end{tabular}

Table 9: Methodology and expected outcome (Activity 2)

\section{Methodology/Plan}

\begin{tabular}{|c|c|}
\hline Methodology/Plan & $\begin{array}{l}\text { Expected Outcome } \\
\text { At the end of the activity, the students will be able to }\end{array}$ \\
\hline $\begin{array}{l}\text { 1. Individual students contemplate on the question/ assignment, } \\
\text { which was previously established based on intuition, } \\
\text { 2. A time of } \mathbf{1 0} \text { Minutes is allotted enhance the plan and submit } \\
\text { the answers as per the discussion point of activity } 1 \text {. }\end{array}$ & $\begin{array}{l}\text { - Analyze the earlier assignment from the perspective of } \\
\text { learnings of activity one within the given time frame. } \\
\text { Develop an action plan to address the given question by } \\
\text { analyzing his strength and weakness. }\end{array}$ \\
\hline
\end{tabular}


Table 10: Pre-implementation Reflection (Activity 2)

\section{Potential Risk}

- Lack of time allotment for contemplating and enhancing the assignment.

- $\quad$ Lack of clarity about the expectation of the teacher regarding the assignment.

- Lack of seriousness in writing the assignment from the practical perspective.

\section{Corrective action}

- Create a template for assignment by mentioning the elements of the plan to help the students to plan as per the expectation

- Share the rubrics of evaluation in advance to bring the clarity of evaluation.

- Sending their action plans to their parents to bring seriousness about the activity.

- Providing a brief example orally about the strategy to address the question from facilitator's (my) perspective by putting myself in their position.

\section{Results and Discussion}

After the implementation of the approach in every session for the selected topic marks of the first internal test was compared with another section which has followed usual teaching-learning practice. The data were subjected to Turkey's comparison test and found that there is a significant difference in means $(p<0.05)$ between two sections. Figure 1 established from the same data indicates that dynamic classroom strategy resulted in better results than the orthodox methodology followed by the other section. Further, the same approach was followed for the subsequent classes with meticulous planning. Eventually, at the end of the semester, all the three test results were subjected to ANOVA (Table 11) and found that there is no significant difference in scoring of the marks among the students with different learning styles. Also, the Box plot (Figure 2) established through the same data indicates that most of the students were able to score good marks (Average 23) irrespective of the learning styles in all the three sessional. This indicates that irrespective of topic and learning styles, effective design of dynamic classroom strategy ensures good learning outcome among the students.

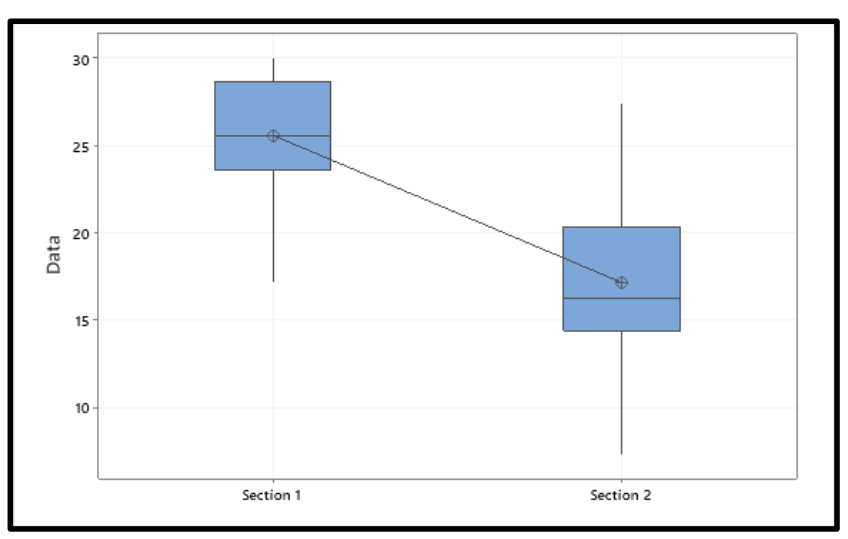

Fig. 1 Box Plot of Internal test results between two sections

Table 11: ANOVA results of Three Internal Test

\begin{tabular}{|l|r|r|r|r|r|}
\hline Source & DF & Adj SS & Adj MS & F-Value & P-Value \\
\hline Active/Reflective & 1 & 4.51 & 4.5114 & 0.36 & 0.547 \\
\hline Sensing/Intuitive & 1 & 4.51 & 4.5141 & 0.37 & 0.547 \\
\hline Visual/Verbal & 1 & 0.01 & 0.0121 & 0.00 & 0.975 \\
\hline Sequential/Global & 1 & 6.79 & 6.7857 & 0.55 & 0.460 \\
\hline Error & 145 & 1792.98 & 12.3654 & & \\
\hline Total & 149 & 1829.54 & & & \\
\hline
\end{tabular}




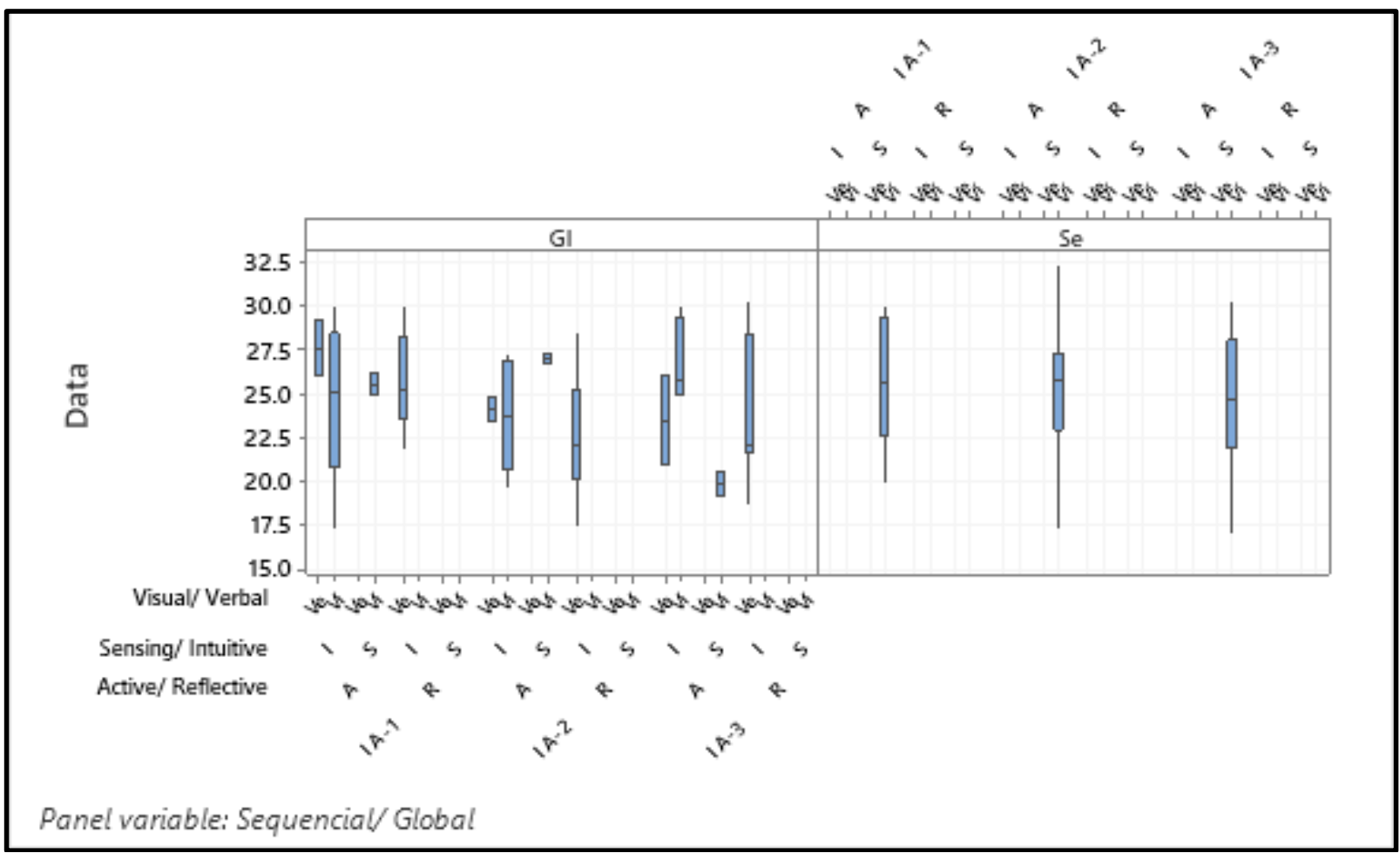

Fig. 2 Box Plot of all three internal test

\section{Conclusions}

The study culminates that learning diversity can be addressed effectively only when a tutor is aware of learning styles and active learning strategies. Also, it is ascertained that the meticulous planning assists the faculty to ensure value-added activities in each of the session. In addition, well-established rubrics helps the students to understand the framework within which they need to participate in the session. Besides, motivation connected to the emotions helps the students participate proactively. Further, the research assisted to ascertain the answers to the RQs

RQ1: Strategies need to be customized depending upon the Socio-Technical requirement of the OBE system.

RQ2: Comprehensive understanding of the pedagogy of engagement and learning styles need to correlate to ensure dynamic classroom/ session.

RQ3: CDOV approach with rationale at every step, risk analysis and reflection on activity can be effectively used to continually improve the knowledge dissemination.

The authors believe that further research in this direction would reinforce the OBE system in engineering institutions. Robust OBE system can be achieved and sustained by enhancing the teaching-learning practice and encouraging the teachers to become role models for the students. The research findings would help the academicians and policymakers to dwell deeper into this arena of students' learning styles and adopt a comprehensive strategy to address the same. Eventually, it can culminate that the scientific planning of the session brings socio-technical changes among the students and in the system.

\section{Acknowledgement}

The authors would like to express the deep sense of gratitude to the management of St Joseph Engineering College for creating an ecosystem for executing the current research in engineering education and IUCEE consortium experts for providing scholarly advice.

\section{References}

Avison D., Baskerville R. and Myers M. (2001) Controlling action research projects, Information Technology and People, 14(1), 28-45.

Bhat S. and Jnanesh N.A. (2013) Transforming Higher Education with Lean Six Sigma, HEF Indian Journal of Higher Education, 3(2), 81-85.

Bhat S., D'Souza R., Bhat S., Raju R. and Kumara P. B. (2020a) Effective Deployment of Outcome Based Education: Strategies based on Motivational Models, Journal of Engineering Education Transformation, 33, 164-169.

Bhat S., D’Souza R., Bhat S., Raju R., and Binu K. G. (2020b) Collaborative Learning for Outcome Based Engineering Education: A Lean Thinking Approach, Procedia Computer Science, 172, 927936.

Bhat, S., Raju R., Bhat S. and D'Souza R. (2020c), Redefining Quality in Engineering Education through the Flipped Classroom Model, Procedia Computer Science, 172, 906-914.

Binu K. G., Vijay V. S., Anusha M. M., Anoop C. V, Bhat S. and D'Souza R. (2020) Influence of Epistemic 
Curiosity on the Study Approaches of First-Year Engineering Students, Procedia Computer Science, 172, 443-451.

Efron S. E., and Ravid, R. (2003) Action Research in Education: A Practical Guide, New York: Guilford Press.

Felder R.M. (1993) Reaching the Second Tier: Learning and Teaching Styles in College Science Education, Journal of College Science Teaching, 23(5), 286-290.

Felder R.M. (1996) Matters of Style, ASEE Prism, 6(4), 18-23.

Felder R.M. and Brent R. (2005) Understanding Student Differences, Journal of Engineering Education, 94(1), 57-72.

Felder R.M. and Henriques E.R. (1995) Learning and Teaching Styles in Foreign and Second Language Education, Foreign Language Annals, 28(1), 2131.

Felder R.M. and Silverman L.K. (1988) Learning and Teaching Styles in Engineering Education, Engineering Education, 78(7), 674-681.

Felder R.M. and Spurlin J.E. (2005) Applications, Reliability, and Validity of the Index of Learning Styles, International Journal of Engineering Education, 21(1), 103-112.

Gilakjani A. P. (2012) A Match or Mismatch Between Learning Styles of the Learners and Teaching Styles of the Teachers, International Journal of Modern Education and Computer Science, 11, 51-60.

Graf S. Viola S. R., Leo T., and Kinshuk (2007) In-Depth Analysis of the Felder-Silverman Learning Style Dimensions, Journal of Research on Technology in Education, 40(1), 79-93.

Litzinger T.A., Lee S.H., Wise JC and Felder R.M. (2007) A Psychometric Study of the Index of Learning Styles." J. Engr. Education, 96(4), 309-319.

Lowman J. (1995) Mastering the techniques of teaching, San Francisco: Jossey-Bass.

Prybutok V. R. and Ramasesh R. (2005) An actionresearch based instrument for monitoring continuous quality improvement, European Journal of Operational Research, 166(2), 293-309.

Reason P. and Bradbury H. (2008) The Sage Handbook of Action Research: Participative Inquiry and Practice, 2nd ed. Los Angeles: Sage Publications.

Schein E.H. (2008) Clinical inquiry/research, The SAGE Handbook of Action Research: Participative Inquiry and Practice, Thousand Oaks, CA: Sage.

Tickle S. (2001) What have we learnt about student learning?: A review of the research on study approach and style, Kybernetes, 30(7/8), 955-969.

Yousef D. A. (2016) The use of the learning styles questionnaire (LSQ) in the United Arab Emirates, Quality Assurance in Education, 24(4), 490-506. 